\title{
Institutional Barriers and World Income Disparities
}

\author{
Ping Wang, Tsz-Nga Wong, and Chong K. Yip
}

\begin{abstract}
Why have the income disparities between fast-growing economies and development laggards widened over the past five decades? How important is the role played by institutional barriers with relation to technology adoption? Using cross-country analysis, we find that more-severe institutional barriers in several representative lag-behind countries actually hinder the process of structural transformation and economic development, causing these countries to fall below a representative group of fast-growing economies despite having similar or even better initial states five decades ago. We also find that institutional barriers have played the most important role, accounting for more than half the economic growth in fast-growing and trapped economies and for more than 100 percent of the economic growth in the lag-behind countries. By conducting country studies, we identify that unnecessary protectionism, government misallocation, corruption, and financial instability have been key institutional barriers causing countries to either fall into the poverty trap or lag behind without a sustainable growth engine. (JEL O41, O43, O47)
\end{abstract}

Federal Reserve Bank of St. Louis Review, Third Quarter 2018, 100(3), pp. 259-79.

https://doi.org/10.20955/r.100.259-79

\section{INTRODUCTION}

Over the past half-century, world income disparities have widened. The gap in real gross domestic product (GDP) per capita relative to the United States between advanced and poor countries has increased. For example, the ratio of average real GDP per capita among the top 10 percent of countries to the bottom 10 percent has increased from less than 20 in 1960 to more than 40 in 1990, and to more than 50 since the turn of the new millennium (Table 1). The huge disparities remain even if we exclude outliners such as oil rich countries in OPEC and former members of the Soviet Union and Yugoslavia. This important issue has induced numerous studies seeking to understand the causes and consequences of such disparities.

Ping Wang is a research fellow at the Federal Reserve Bank of St. Louis, a professor at Washington University in St. Louis, and a research associate at the National Bureau of Economic Research; Tsz-Nga Wong is an economist at the Federal Reserve Bank of Richmond; and Chong K. Yip is a professor at the Chinese University of Hong Kong.

(c) 2018, Federal Reserve Bank of St. Louis. The views expressed in this article are those of the author(s) and do not necessarily reflect the views of the Federal Reserve System, the Board of Governors, or the regional Federal Reserve Banks. Articles may be reprinted, reproduced, published, distributed, displayed, and transmitted in their entirety if copyright notice, author name(s), and full citation are included. Abstracts, synopses, and other derivative works may be made only with prior written permission of the Federal Reserve Bank of St. Louis. 
Table 1

Per Capita Income Ratio Between Top and Bottom 10\% Countries

\begin{tabular}{cccc} 
Year & $\begin{array}{c}\text { Average per capita } \\
\text { income, bottom 10\% }\end{array}$ & $\begin{array}{c}\text { Average per capita } \\
\text { income, top 10\% }\end{array}$ & Ratio \\
\hline 1960 & 606.2 & $12,015.0$ & 19.8 \\
1970 & 758.1 & $16,072.5$ & 21.2 \\
1980 & 716.9 & $24,545.9$ & 34.2 \\
1990 & 637.0 & $26,390.7$ & 41.4 \\
2000 & 657.9 & $35,522.1$ & 54.0 \\
2010 & 852.0 & $45,277.3$ & 53.1
\end{tabular}

SOURCE: Penn World Table 8.1 (in millions of 2005 U.S. dollars).

The conventional framework developed by Lucas $(1990,2000)$ and Prescott (1998) uses a neoclassical aggregate production function to explain relative income gaps. In addition to differences in per capita capital, the residual gaps are calibrated as measures of relative total factor productivities (TFPs). This tends to result in unreasonably large gaps in TFPs, thereby leading to further analyses extending the basic framework. Among others, various forms of institutional barriers are believed to play an important role. Such barriers could relate to physical capital investment due to financial market frictions, as considered by Aghion, Howitt, and Mayer-Foulkes (2005) and Buera and Shin (2013). These barriers may also relate to frictions associated with human capital or health investment, as in Wang and Wang (2015). Moreover, they may relate to technology adoption, as in Basu and Weil (1998), or to technology assimilation, as in Wang, Wong, and Yip (2017).

The main point to be addressed in this article is why the income disparities between fastgrowing economies and development laggards have widened. More specifically, we want to understand the following: How important is the role played by institutional barriers with relation to technology adoption? To illustrate, we select a set of 10 fast-growing economies. This set includes Asian countries and African economies that are perceived as better performing. In contrast, we select a set of 10 development laggards. Beyond the typical candidates of countries mired in the poverty trap, this set includes countries with similar or even better initial states than some of the fast-growing countries, but with divergent paths of development leading to worse macroeconomic outcomes. That is, among development laggards, we choose two subgroups, one consisting of trapped economies and another of lag-behind countries. Over the past five decades, the ratios of average real GDP per capita between the 10 fast-growing economies and the five trapped economies have widened by almost nine times, whereas the comparable figures between the fast-growing economies and the five lag-behind countries have been almost four times.

Using cross-country analysis, we find that a key factor for fast-growing countries to grow faster than the United States and for trapped economies to grow slower than the United States is the relative TFP, which may be technology driven and not related to institutional barriers. 
Yet more-severe institutional barriers in the lag-behind countries actually hinder the process of structural transformation and economic development, causing these countries to fall behind the fast-growing economies despite having similar or even better initial states five decades ago. Overall, we find that institutional barriers have played the most important role, accounting for more than half the economic growth in fast-growing and trapped economies and for more than 100 percent of the economic growth in the lag-behind countries. By conducting country studies, we identify that unnecessary protectionism, government misallocation, corruption, and financial instability have been key institutional barriers causing countries to either fall into the poverty trap or lag behind without a sustainable growth engine. Such barriers have created frictions or distortions to capital markets, trade, and industrialization, subsequently preventing these countries from advancing.

\section{THE ORGANIZING FRAMEWORK}

To illustrate, we use Acemoglu's (2009) version of Basu and Weil's (1998) as the organizing framework. Specifically, consider a representative firm in country $j$ that employs capital $K$ and labor $L$ to manufacture a final product $Y$ using a well-behaved aggregate production function that satisfies the constant-returns-to-scale property. Thus, country $j$ 's per capita real income at time $t$ is given by

$$
y_{j, t}=\frac{Y_{j, t}}{L_{j, t}}=\frac{A_{j, t} F\left(K_{j, t}, L_{j, t}\right)}{L_{j, t}}=A_{j, t} f\left(k_{j, t}\right),
$$

where $A$ measures TFP, $k=K / L$ is the capital-labor ratio, and $f(k)=F(k, 1)$. Assume that $F$ takes the Cobb-Douglas form with a capital income share $\alpha \in(0,1)$. We consider the United States as on the technology frontier, whose per capita real income is expressed as

$$
y_{U S, t}=A_{U S, t} k_{U S, t}^{\alpha} \text {. }
$$

We follow the Basu-Weil-Acemoglu framework, assuming that the ability for country $j$ to adopt production technology from a source country on the technology frontier, namely, the United States, depends on the extent of adoption barriers. Let technology adoption of a firm in country $j$ take a simple form:

$$
A_{j, t}=\tau_{j, t} A_{U S, t} \min \left[1,\left(k_{j, t} / k_{U S, t}\right)^{\zeta_{j}}\right],
$$

where $\tau_{j}$ measures the relative TFP of country $j$ to the United States, and $\zeta_{j} \in[0,1-\alpha]$ captures the foreign technology's degree of inappropriateness, which may be referred to as country $j$ 's barriers to adoption. When $\zeta_{j}=0, \min \left[1,\left(k_{j, t} / k_{U S, t}\right)_{j}\right]$ is the highest (equal to 1$)$-we call this case the absence of adoption barriers. In contrast, when $\zeta_{j}=1-\alpha$, the adoption barriers are most severe.

We can then write country $j$ 's per capita real income relative to the United States, or in short, relative income, as follows: 


$$
\frac{y_{j, t}}{y_{U S, t}}=\tau_{j, t} \min \left[1,\left(\frac{k_{j, t}}{k_{U S, t}}\right)^{\zeta_{j}}\right]\left(\frac{k_{j, t}}{K_{U S, t}}\right)^{\alpha} .
$$

It is clear that when $\zeta_{j}=0$, the expression reduces to the Lucas (2000) benchmark. Hence, the consideration of adoption barriers generalizes the Lucas benchmark, permitting better development and accounting for cross-country income disparities.

Notably, the adoption barrier parameter $\zeta_{j}$ may also capture other types of barriers that are not directly linked to technology. Examples of such include corruption, waste of resources, mismatched deficiencies, and capital market frictions. This parameter is country-specific, depending on a country's market environment and economic institutions. Throughout the remainder of the article, we shall refer to this as the institutional barrier parameter.

\section{CROSS-COUNTRY ANALYSIS}

To elaborate on this parameter without using the entire sample of countries, we select two sets of representative countries. The first set contains 10 fast-growing economies:

(i) four Asian Tigers known for their growth miracles-Hong Kong, Singapore, South Korea, and Taiwan;

(ii) two potential future Tigers of the Association for Southeast Asian Nations (ASEAN) Malaysia and Thailand;

(iii) two emerging giants-China and India; and

(iv) two African miracles-Botswana and Mauritius.

Over the past five decades, these countries all experienced rapid, sustained growth. While most of them grew 2 percent or more during the entire period, India started late and Mauritius slowed down after the turn of the new millennium. While some performed better initially (e.g., Hong Kong and Singapore), others caught up quickly (e.g., China and India). These countries are typically singled out as development miracles.

The second set includes 10 development laggards:

(i) five sub-Saharan African poor countries in poverty traps-Comoros, Côte d'Ivoire, Ghana, Kenya, and Uganda;

(ii) three Latin American countries falling behind newly industrialized Asian economies, despite better initial conditions-Argentina, Brazil, and Chile;

(iii) one lag-behind European country-Greece; and

(iv) one lag-behind Asian country-the Philippines.

All of the five trapped economies experienced negative growth and are frequently chosen in the literature when discussing poverty traps. The other five lag-behind countries' relative income growth is insignificant, between -1 and 1 percent. They are more or less trapped in the middle income level, around 20 to 30 percent of the U.S. income level since 1960. The selection of these countries is particularly interesting because they have similar or even better initial states than some of the fast-growing countries, but they take divergent paths of development resulting in less-desirable aggregate outcomes. 


\section{Figure 1}

\section{Relative Income of Asian Tigers, Other Fast-Growing, Trapped, and Lag-Behind Countries}

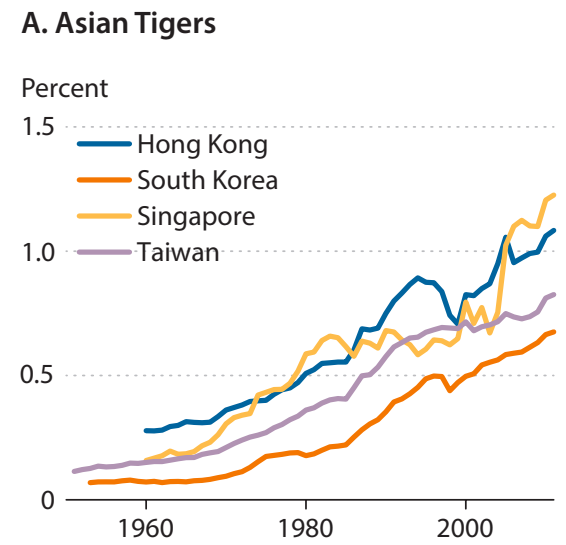

C. Trapped Countries

Percent

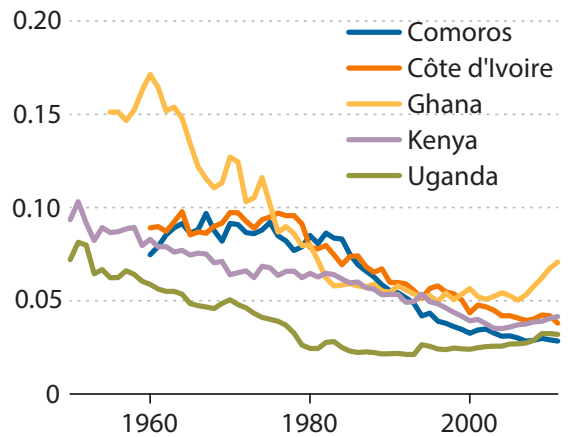

\section{B. Other Fast-Growing Countries}

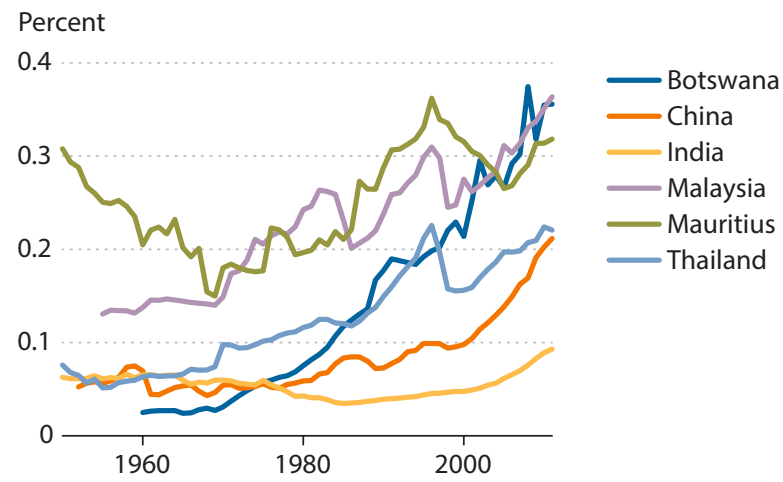

D. Lag-Behind Countries

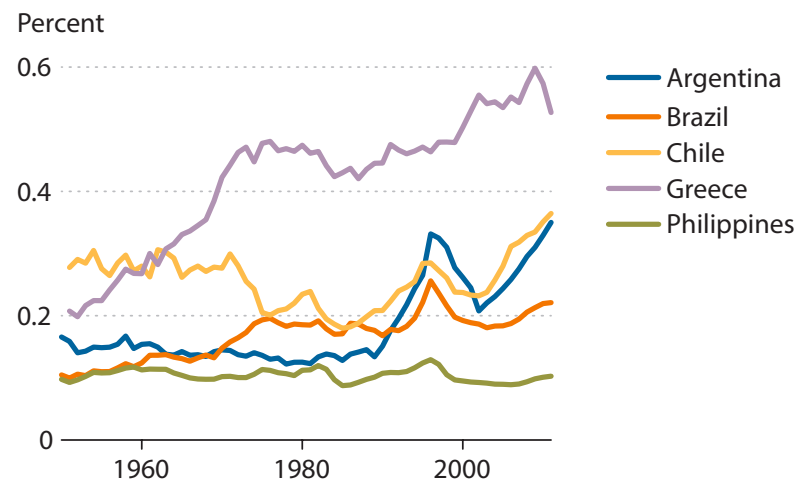

SOURCE: Penn World Table 8.1 (in millions of 2005 U.S. dollars).

\subsection{Data and Parameterization}

For our quantitative analysis throughout (including Figure 1 and Tables 1-3), we use the Penn World Table 8.1 (PWT) for the period 1950-2011, for which real income measures are output-based and all relative income measures are with respect to the United States (see the Appendix for details). In Figure 1, we plot each country's relative income over the sample period. We divide the 20 countries into four panels: (A) the four Asian Tigers; (B) other fastgrowing economies; (C) five sub-Saharan African poor countries in poverty traps; and (D) five lag-behind countries. One can see the miraculous development experienced by fast-growing economies during various episodes, as well as the economic miseries suffered by development laggards. One can also see that countries in Panels A and B experienced much faster growth over long episodes. In contrast, countries in Panel C showed a downward trend, whereas countries in Panel D had a moderate trend in relative income for a long time. 


\section{Wang, Wong, Yip}

Our calibration exercise essentially summarizes the relative income of each country by the two parameters - the TFP ratio, $\tau_{j}$, and the institutional barrier, $\zeta_{j}$. Following Hall and Jones (1999), we set $\alpha=1 / 3$. We calibrate $\tau_{j}$ and $\zeta_{j}$ to match the average level of relative income (in logs) and the average lag difference of relative income (in logs). The parameters are calibrated with the generalized method of moments whenever there does not exist any parameter within the parameter space to match the two targets.

\subsection{Results}

Our cross-country quantitative results are summarized in Table 2 (for fast-growing economies) and in Table 3 (for development laggards). One can see that the average growth rates of the fast-growing countries over the sample period of 1960-2011 is about 2.90 percent higher than that of the United States, much higher than that of the lag-behind countries $(0.05$ percent relative to the United States) and the trapped economies ( -1.56 percent relative to the United States). Although the initial development status of these fast-growing economies (11.58 percent of the U.S. level) was ahead of the trapped ones (6.82 percent), it was below the other laggards (26.27 percent).

Simple development accounting analysis allows us to calibrate the institutional barrier parameters and the relative TFPs. For the fast-growing economies, the average institutional barrier parameter is about 0.4378 , comparable with the figure for the trapped economies $(0.4253)$ but noticeably lower than that for the lag-behind countries (0.4965). While the average relative TFP of the fast-growing economies (0.8769) is marginally higher than the figure for the lagbehind countries (0.8558), it is far above that for the trapped economies (0.6168).

One may therefore conclude that a key factor for fast-growing countries to grow faster than the United States and for trapped economies to grow slower than the United States is the relative TFP. More interestingly, more-severe institutional barriers in the lag-behind countries actually hinder the process of their structural transformation, causing these countries to fall below the fast-growing economies despite having similar or even better initial states five decades ago.

To complete the analysis, we perform standard growth accounting to compute the contribution of the institutional barriers to the long-term development of various countries compared with TFP advancement and capital deepening. We find that for all countries, institutional barriers have played the most important role: They account for more than half the economic growth in fast-growing and trapped economies-52.62 and 66.31 percent, respectively-and for more than 100 percent (101.70 percent) of the economic growth in the lag-behind countries.

While the overall message delivered above is clear-cut, the individual country's quantitative results are not entirely convincing. For example, the calibrated institutional barriers in Hong Kong and Taiwan may seem too high, whereas such barriers in China, Kenya, Uganda, and Brazil may seem too low. This is a typical problem of cross-country analysis. To further understand the role of institutional barriers, it is profitable to conduct more detailed country studies, to which we now turn. 
Table 2

\section{Cross-Country Quantitative Analysis-Fast-Growing Economies}

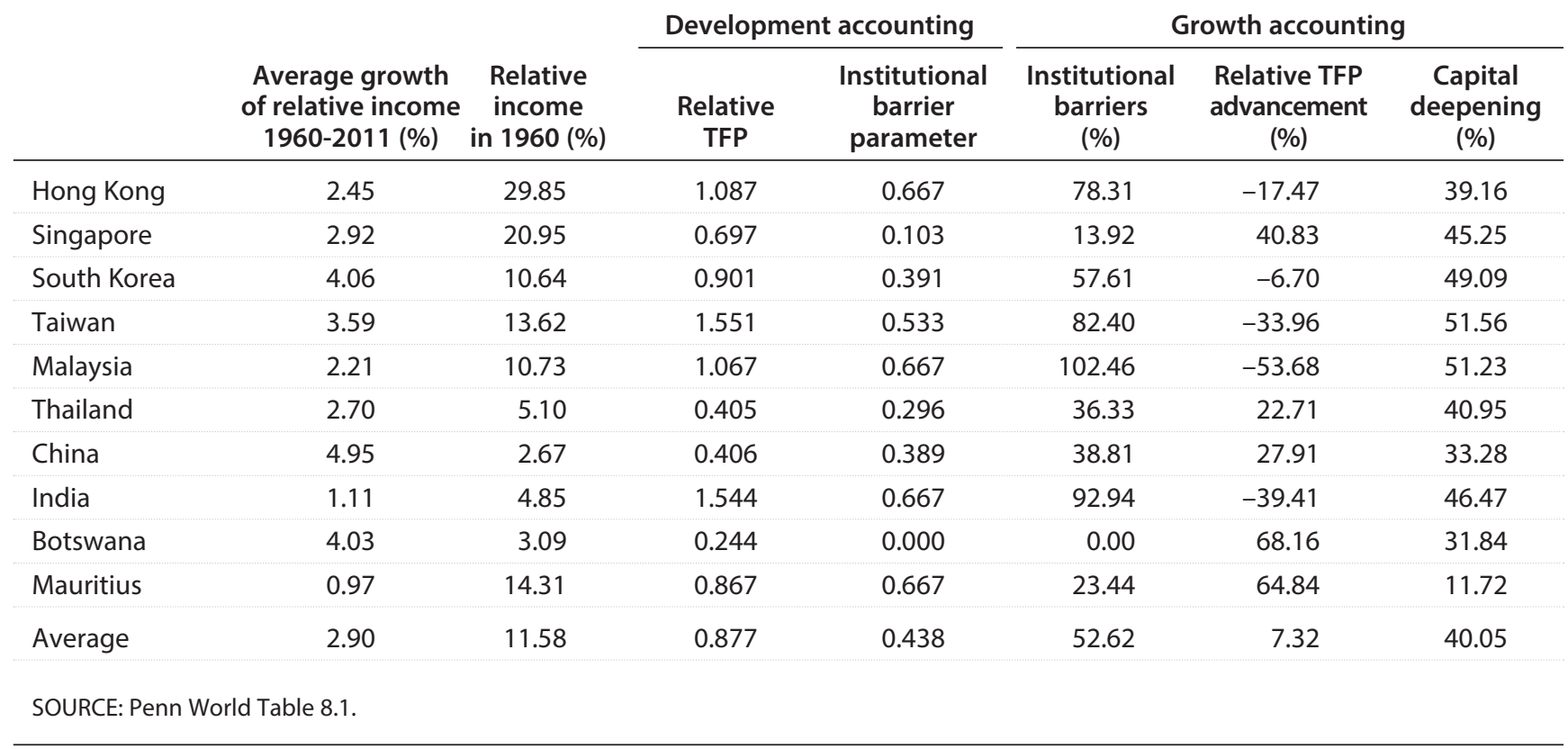

Table 3

Cross-Country Quantitative Analysis-Development Laggards

\begin{tabular}{|c|c|c|c|c|c|c|}
\hline \multirow[b]{2}{*}{$\begin{array}{c}\text { Average growth } \\
\text { of relative income } \\
\text { 1960-2011 (\%) }\end{array}$} & \multirow[b]{2}{*}{$\begin{array}{c}\text { Relative } \\
\text { income } \\
\text { in } 1960(\%)\end{array}$} & \multicolumn{2}{|c|}{ Development accounting } & \multicolumn{3}{|c|}{ Growth accounting } \\
\hline & & $\begin{array}{c}\text { Relative } \\
\text { TFP }\end{array}$ & $\begin{array}{c}\text { Institutional } \\
\text { barrier } \\
\text { parameter }\end{array}$ & $\begin{array}{l}\text { Institutional } \\
\text { barriers } \\
(\%)\end{array}$ & $\begin{array}{c}\text { Relative TFP } \\
\text { advancement } \\
(\%)\end{array}$ & $\begin{array}{c}\text { Capital } \\
\text { deepening } \\
(\%)\end{array}$ \\
\hline \multicolumn{7}{|l|}{ omies } \\
\hline-2.01 & 4.34 & 0.596 & 0.667 & 61.65 & 7.53 & 30.82 \\
\hline-2.76 & 8.26 & 1.420 & 0.667 & 74.95 & -12.42 & 37.47 \\
\hline-0.83 & 10.28 & 0.508 & 0.509 & 187.76 & -210.81 & 123.05 \\
\hline-1.32 & 6.46 & 0.132 & 0.000 & 0.00 & 52.03 & 47.97 \\
\hline-0.85 & 4.73 & 0.428 & 0.285 & 7.18 & 84.42 & 8.40 \\
\hline-1.56 & 6.82 & 0.617 & 0.425 & 66.31 & -15.85 & 49.54 \\
\hline \multicolumn{7}{|l|}{ ds } \\
\hline-0.58 & 43.51 & 0.734 & 0.667 & 73.66 & -10.48 & 36.83 \\
\hline 0.42 & 15.56 & 0.328 & 0.000 & 0.00 & 36.79 & 63.21 \\
\hline 0.45 & 25.87 & 1.382 & 0.667 & 284.46 & -326.69 & 142.23 \\
\hline 0.61 & 34.71 & 1.113 & 0.667 & 185.22 & -177.84 & 92.61 \\
\hline-0.65 & 11.68 & 0.722 & 0.483 & -34.85 & 158.93 & -24.07 \\
\hline 0.05 & 26.27 & 0.856 & 0.497 & 101.70 & -63.86 & 62.16 \\
\hline
\end{tabular}

A. Trapped Economies

Comoros

Côte d'Ivoire

Ghana

Kenya

Uganda

Average

B. Other Laggards

Argentina

Brazil

Chile

Greece

Philippines

Average

0.05
SOURCE: Penn World Table 8.1. 


\section{COUNTRY STUDIES}

In what follows, we document for each country the key country-specific economic conditions and institutions that are relevant to our study. For general institutional background for each of the 20 countries, we refer the reader to the references listed in the Appendix.

\subsection{Fast-Growing Economies}

We begin by documenting some developmental and institutional details of the 10 fastgrowing economies. For brevity, we focus on factors more likely to account for our quantitative findings.

Hong Kong. As shown in Figure 1A, Hong Kong's relative income (to the United States) rose sharply, except during the Asian financial crisis and the internet bubble periods (late 1990s and early 2000s). In the 1960s and 70s, Hong Kong's wider manufacturing industry successfully developed a reputation as a low-cost, labor-intensive original equipment manufacturing center by producing goods for export to Western countries. Morawetz (1981) argues that the mass production of Hong Kong's garment and general textile industry started with the American production lines built to produce supplies for the Korean War. Wan (2004) also provides cases for the electronics industry, but they are not that significant. Ever-increasing wages and land prices in the late 1970s seriously threatened the original equipment manufacturing strategy adopted by most manufacturing firms in Hong Kong. Since China's opening-up policy in 1978, many firms in Hong Kong have transformed themselves into service providers, from manufacturing to trading. A rapid transition to a service-based economy then took place in the 1980s, and Hong Kong further grew to become a financial center in the 1990s.

Singapore. The growth of Singapore's relative income is particularly impressive before the mid-1980s and after the internet bubble (see Figure 1A). By the turn of the century, the manufacturing and financial sectors contributed to almost half the country's GDP. The government set as high priority the high-tech industries, such as electronics, chemicals, and biotechnology. To achieve this goal, Singapore switched from labor-intensive to capital-intensive production by adopting a high-wage policy (compare with Otani and Sassanpour, 1988). But the exchange rate fluctuations in the early 1980s caused a serious recession that forced the government to set ceilings for nominal wages. Following the exchange rate depreciation in the mid-1980s, the economy started its recovery. Toward the end of the 1990s, Singapore became a world technology leader, particularly in its main electronics and biotech industries (compare with Lim and Lloyd, 1986).

South Korea. Figure 1A suggests South Korea's relative income rose steadily over the entire sample period. South Korea pursued a government-led, export-oriented growth strategy and shifted from import-substitution to export-oriented industrialization in the early 1960s. The Five Year Economic Development Plan of 1967-71 focused on shifting from primary exports to labor-intensive manufacturing sectors. Starting in 1970, the country shifted to promote heavy industries through the supply of cheap credit. In the 1980s, although the country had to deal with overinvestment or excess capacity negative growth, it stuck to its strategy of long- 
term investment in the high-tech exports, which contributed to the great takeoff in the following decade.

During its industry transformation, South Korea benefitted greatly from Japan, as documented by Kim (1997) and Wan (2004). Note that South Korean high school students were required to take Japanese language courses. Moreover, the country's business structures, inclusive of both large conglomerates (chaebols) and organized international trading companies (general trading corporations), resembled those of Japan, not to mention its significant technology transfers in the electronics industry (Sony to Samsung and Hitachi to LG) and the automotive industry (Honda to Hyundai).

With the onset of the Asian financial crisis in 1997, the financial sector liberalized and the proactive industrial policy to promote exports almost came to an end. However, with international lending and economic restructuring, South Korea recovered after only 18 months from the start of the crisis. Globalization of South Korea's industries since then reached a milestone in the nation's history, and the country joined the high-income group shortly after, becoming only the second in Asia to do so following the lead of Japan.

Taiwan. Similar to South Korea, Taiwan's relative income rose steadily over the entire sample period (see Figure 1A). During the 1960s and 70s, the Taiwan economy became industrialized and technology oriented. It was the second-fastest growing state in Asia after Japan. Starting in 1974, Chiang Ching-kuo implemented the Ten Major Construction Projects, the beginning foundations that helped Taiwan transform into an export-led growing economy. Exports became the main momentum to growth and industrialization and accumulated huge foreign reserves from a trade surplus.

Note that the Japanese rule before and during World War II brought changes in the public and private sectors, including rapid communications, good transportation systems throughout much of the island, and compulsory primary education. As documented by Kuo (1983) and Li (1988), Taiwan has benefitted from Japan, particularly in agricultural and textile technology. Moreover, Tatung was established in 1918, and it later became Taiwan's consumer electronics giant. The Sanyo to Sampo technology transfer also played an important role in broadening the range of electronics products.

However, the rapid development of Taiwan's modern IT industry in the past two decades was mostly influenced by the United States. As documented by Wan (2004) and Lee and Wang (2011), a series of key stepping stones helped Taiwan grow into an IT giant. In 1966, General Instrument built the largest foreign headquarters in Taipei County, and it was crucial to the development of machineries and tools. In 1970, RCA started its technology transfer to Taiwan. Robert Tsao was trained at RCA and later returned to Taiwan to establish the country's first major IT firm, the United Microelectronics Corporation (UMC), in 1980. Similarly, Texas Instruments started its technology transfer to Taiwan in 1970. Its senior vice president Morris Chang returned to Taiwan to establish the Taiwan Semiconductor Manufacturing Company (TSMC) in 1987. The semiconductor industry has formed a major part of Taiwan's IT industry. It overtook that of the United States, which was second only to Japan, in 2007. TSMC and UMC are the two largest contract chipmakers in the world, and MediaTek is the fourth-largest fabless supplier globally. Despite their success, small and medium-sized businesses still make 


\section{Wang, Wong, Yip}

up a significant portion of the businesses in Taiwan (i.e., they account for 85 percent of the industrial output), unlike in Japan and South Korea. The small and medium-sized enterprises rely on the importation of key components and advanced technology from the United States and Japan.

Malaysia. Since it became independent in 1957, Malaysia has grown remarkably in the region. It is the third-largest economy among countries in the ASEAN. During the second half of the past century, Malaysia grew an average of about 6.5 percent per annum, reaching a growth rate of 8 percent during its golden era, between 1980 and 1995 (Malaysia Yearbook, 2015). Its growth trend in relative income is plotted in Figure 1C. The major economic activities of the country are international trade and manufacturing. Malaysia is an exporter of natural and agricultural resources and is the largest Islamic banking center in the world.

Since the implementation of the controversial New Economic Policy in 1971, the predominantly mining and agricultural-based economy began a transition toward a more multi-sector industrial economy. The Mahathir Mohamad administration carried out many mega-projects in the 1980s that generated rapid economic growth and urbanization. Nevertheless, the financial markets were hit hard by the Asian financial crisis by the end of the past century. Although Malaysia's GDP declined dramatically by 7.5 percent in 1998, it rebounded by 5.6 percent in the following year (Malaysia Directory, 2008). The post Y2K slump of 2001 did not affect Malaysia as much as other countries.

Thailand. From Figure 1B, one can see that Thailand's relative income rose, except during the Asian financial crisis and internet bubble periods. Similar to the Asian Tigers, Thailand is a heavily export-dependent country, with exports accounting for more than two-thirds of its GDP. It completed industrial transformation two decades ago despite its relatively slow urbanization process.

The Srisdi regime, in power from 1957-73, introduced the market-oriented importsubstitution industrialization that led to a period of rapid growth in 1958, with an average growth rate of 7 percent a year since then. From the 1970s to 1984, Thailand suffered from many economic problems, including reduced American investments, sizable current account deficits, high inflation due to two oil crises, unstable domestic politics, and unfriendly international politics. To deal with these economic problems, the Thai government devalued the baht three times in the early 1980s. As a result, beginning in 1987 the economy improved because net exports rose and foreign direct investment increased (especially from Japan); however, many economic problems persisted. For example, along with a huge current account deficit (averaged at 5.4 percent of GDP per year), a domestic capital shortage and rising external debt also occurred. All this led to the currency attack in 1997 that started the regional Asian financial crisis-the baht was forced to float starting July 2, 1997. Nevertheless, the economy began to recover in 1999 because of both internal and external factors. Internally, the government expanded its investment under the Thaksin Shinawatra administration. Externally, exports increased sharply because of both a weak baht and strong growth of the region.

China. China pursued an export-oriented growth strategy in the context of late industrialization toward the end of the 1970s, when East Asian early-starters felt the need to relocate 
and diversify their costly production bases. Among the late-industrializing nations, China has adopted a comprehensive export-led growth strategy, particularly since the 1992 Southern Tour announcement by Deng Xiao-ping. It provided the correct incentives from all government policies, including industry and trade policies, regulations (new laws and rules in all aspects of Chinese economic and trade reforms), administrative guidance and support (establishment of economic and technological development zones and directive measures to lead finance and investment to the key sectors), and a foreign direct investment (FDI) policy. As indicated in Figure 1B, China's relative income has risen sharply since then.

China's policies concurrently affect all sectors of exports, including primary goods, intermediate goods, and finished products. Its processing trade policy exempts imports for production to exports from tariffs and value-added tax, and it is a major support to exporters. Its exports through export and special economic zones have been encouraged, and its imports for research and development (R\&D)-center establishment and operation are also exempt from tariffs and value-added tax. China's broad support for exports represents a departure from the promotion of selective sectors or the products approach of its neighbors in the 1970s. China took only two decades to make itself the number-one exporter of the world. The FDI share in China's exports increased from 1.94 percent in 1986 to 54.8 percent in 2003.

On average, during 1990-2004, China's annual real GDP growth rate was 10 percent, which remains one of the highest in the world. International trade makes up a major portion of China's GDP, and it exceeded \$2.4 trillion at the end of 2008. However, aside from the external factors of trade and FDI, the Chinese economy experienced a series of internal structural transformations since the opening-up economic reform in 1979. These transformations include rural industrialization, reform of state-owned enterprises, modernization of the banking sector, and the recent proposal of fighting corruption.

India. As indicated by Figure 1B, India's growth came much later than China's. During 1950-90, India's per capita income grew at an average annual rate of only about 2 percent, a result due to the Indian government's implementation of restrictive trade, financial, and industrial policies. The Indian state took control of major heavy industries, by including additional licensing requirements, capacity restrictions, and limits on the regulatory framework. Following the foreign exchange crisis of 1957-58 (Sinha, 2004), trade policies shifted toward selfsufficiency, and the government gradually tightened control by increasing statutory liquidity and cash reserve requirements.

Despite all these regulations, the government invested heavily in $R \& D$ in the postindependence era. Many organizations were established to commercialize research outcomes. In terms of human capital accumulation, the government started different programs for developing engineers and scientists. The average R\&D expenditure was 0.4 percent of GDP during 1950-90, but it surged to an average of 0.8 percent of GDP during 1991-2005, twice as much as the pre-reform period. In the late 1970s, the Indian government opened the economy by liberalizing both international trade and the capital market, leading to rapid growth in the early 1990s. As argued by Rodrik and Subramanian (2005), the trigger for India's economic growth was an attitudinal shift on the part of the national government in 1980 in favor of 


\section{Wang, Wong, Yip}

private businesses. Specifically, this shift is the pro-business attitude of Indira Gandhi, who returned to power in 1980 to garner political support from existing business groups. Such a change in the attitude of the national government toward the private sector created a positive atmosphere for investors' animal spirit.

The final trigger of the major economic reform of Manmohan Singh in the 1990s was due to the well-known 1991 balance-of-payment crisis. The economic reform that helped India's recovery was the condition of the emergency loan imposed by the International Monetary Fund (IMF) on the Narasimha Rao government. This reform ended the protectionist policies followed by previous Indian governments and started the liberalization of the economy toward a free-market system. This event led to an average annual growth rate that exceeded 6 percent in per capita terms during 1990-2005.

Botswana. During 1966-88, Botswana's GDP grew at an annual rate of 14.5 percent (The World Bank Profile, 2004). Its strong performance branded Botswana as the African Miracle. Rapid export growth followed the discovery of diamonds, with mining contributing 13 percent to GDP in 1975 to more than 50 percent by the end of the 1980s. Botswana then sought to diversify the economy by encouraging investment from abroad.

According to Sachs and Warner (1997), reform took place in 1979 that led to the country being open to international markets. During 1997-2002, its average GDP growth rate decreased to 5.9 percent. Moreover, AIDS has been a serious problem for Botswana: In 2002, HIV prevalence in Botswana was 39 percent of the people 15-49 years of age (The World Bank Profile, 2004), one of the highest in the world. This has not only raised mortality but also reduced labor productivity.

Mauritius. Another miraculous performer in Africa is Mauritius, whose success is due to its early reform that took place in 1968 . The reform instituted a spectacular economic transformation into tourism and out of sugar production. Consequently, agriculture in GDP composition dropped from 24 percent in 1970 to 5 percent in 2007, and services increased from 56 to 74 percent in the same period. During 1970-99, the average annual growth of export volumes was 5 percent. It began at only 1 percent in the 1970s, increased to about 10 percent in the 1980s, and then was 5 percent (mode 12) in the 1990s. Given its economic focus on tourism, the technological assimilation of Mauritius is not expected to be important, as is confirmed by its low value of the assimilation parameter at 0.0037. As shown in Figure 1B, the growth trend in relative income is most noticeable during 1968-96.

\subsection{Development Laggards}

We next turn to documentation of developmental and institutional details of the five trapped and five lag-behind countries.

Comoros. Income disparity between Comoros and the United States has widened, as shown in Figure 1C. Comoros was colonized by France in 1841 and was transformed into a plantationbased economy. It declared independence in 1975. However, Comoros has experienced political interruptions since then, with its on-and-off independence from France. 
Agriculture dominates the production activity of Comoros, and it features three main cash crops: ylang-ylang (for perfume), vanilla, and coconut. The country's high total fertility rates created serious population pressure because of the people's fear of hunger. Not surprisingly, its education level was low as well. Moreover, the government deficits were large because the country lacked stable tax revenues. In the past few decades, the economy of Comoros mainly relied on foreign financial and technical assistance.

Côte d'Ivoire. Real GDP per capita of Côte d'Ivoire rose in the 1960s-70s but fell afterward (see Figure 1C). Its real GDP per capita in 2003 was about the same as that in the early 1960s. Underpinning the per capita output decline since the late 1970s are the following: rapid population growth (3.95 percent for the first period of 1960-79 and 3.26 percent for the second period) and a decrease in capital investment. (The growth rate of gross capital formation per capita was 5.61 percent for the first period and -2.90 percent for the second period.)

Côte d'Ivoire has become dependent on raw commodities, particularly cash crops such as cocoa. Over the past 40 years, cocoa output has grown to dominate Côte d'Ivoire's economy and world production. Its cocoa output was 1.4 million tons in 2001, equivalent to about 40 percent of the world's output. The nominal and real cocoa prices in the world market increased until they hit an all-time high in 1977. Then the prices collapsed and never fully recovered. And cocoa exports dominate Côte d'Ivoire's trade and economy. By 2000, raw cocoa represented 80 percent of the country's commodity exports, more than 50 percent of all exported goods and services and 21 percent of GDP. The structural problem of the Côte d'Ivoire economy was caused by its dependence on cocoa production. Cocoa production is not a very profitable business because there is a long period of investment and no alternative use of the land. The life cycle of cocoa is nearly four decades while it takes seven years to finish just the planting process. In addition, the country's terms of trade have deteriorated seriously since the late 1970s because of the fall in international cocoa prices and the fluctuations in foreign exchange rates. In short, the gamble of Côte d'Ivoire on cocoa to finance development efforts failed.

The support of foreign aid (from IMF and World Bank) is crucial to the economy. Note that Côte d'Ivoire is one of the most corrupt countries in the world (compare with Easterly, 2001).

Ghana. As shown in Figure 1C, income disparity between Ghana and the United States had widened until very recently because the 2008 financial tsunami did not harm Ghana's economy as much as it did the rest of the world. Attaining its political independence in 1957, the Ghana government adopted a fast-track strategy by launching state-owned import substitution industries in the 1960s. In 1970, Ghana had one of the most diverse and dynamic manufacturing sectors in sub-Saharan Africa. To understand the surge that occurred until the early 1970s, we find that, by ignoring the outlier of 1968, a clear negative correlation exists between the government spending-GDP ratio and per capita GDP. This finding can be understood by Prescott's (1998) suggestion that, for developing countries, government size can be used as a measure of distortions. However, as Ghana pursued non-selective industrialization policies behind high barriers of protection, its industry failed to develop adequate industrial capabilities and infrastructure. The Ghanaian industrial structure is typical of a low-level industrial- 


\section{Wang, Wong, Yip}

ization, showing a natural evolution from traditional to simple processing and assembly activities. Consequently, growth rates slowed down and, with declining revenues from the primary exports that had financed industry, even turned negative. Thus, structural reform policies were undertaken in the 1980s. Growth resumed by the end of the 1990s. Unlike the formal technological effort in Ghanaian manufacturing, practically all industrial R\&D in Ghana was conducted by public institutions rather than by enterprises. The R\&D effort declined sharply in the 1980s, and it was well below the critical mass needed to make a significant contribution to the absorption, adaptation, or creation of technology (Lall, 1990).

Kenya. Income disparity between Kenya and the United States widened over the entire sample period (see Figure 1C). Following Kenya's emergence as an independent nation in 1963, the years were marked by rapid growth of domestic products, strong fiscal performance, low rates of inflation, and manageable external accounts. Since the early 1970s, growth has slowed because of two oil crises, as Kenya is heavily dependent on imported petroleum. Other international economic events occurred as well, such as the collapse of the East African Community, the major market for Kenyan manufactured goods. International recession and high international interest rates resulted in a steady tightening of the foreign exchange constraint on growth. Dramatic swings in the prices of Kenya's key exports-coffee and tea-compounded the already difficult problems of economic management. Real prices for raw cocoa, cotton, and coffee increased in world commodity markets in 1960 until they hit all-time highs in 1977. After 1977, real prices crashed, and on average they have declined steadily ever since. During 1977-2003, coffee production did not increase, and real prices declined. Other factors contributing to the poor growth performance of Kenya include rapid population growth, an AIDS outbreak, poor infrastructure, and the extended and recurrent banking crisis since the mid-1980s.

Uganda. Figure 1C indicates that income disparity between Uganda and the United States widened before 1980; afterward, the gap remained largely unchanged. Uganda became independent from the United Kingdom in 1962. At that time, more than 80 percent of households lived in rural areas, with the majority earning a living from quasi-subsistence agriculture. Unfortunately, this independent nation suffered a sharp economic downturn in the 1970s and 80s. The prolonged recession was due to the expulsion of South Asians in 1972, the administration of Idi Amin (the so-called State of Blood), the outbreak of the Uganda-Tanzania War in 1978-79, and the Bush War by the National Resistance Army in 1981-86.

In 1986, the government (with the support of foreign countries and international agencies) attempted to rehabilitate the economy devastated during the regime of Idi Amin and the subsequent civil war. However, the economy was still in very poor condition. Its agriculture sector accounted for 56 percent of real GDP, with coffee as its main export. (Coffee's price fell sharply in the late 1970s.) The reform in 1988 helped the agriculture-based export expansion, causing an annual growth rate of 14 percent. Inflation was at 240 percent in 1987 and 42 percent in June 1992.

Argentina. As shown in Figure 1D, Argentina's relative income fell slightly until 1990; since then there have been some upward, though volatile, movements. Argentina is the third-largest 
economy in Latin America and was one of the richest countries in the world in the early twentieth century. However, after the Great Depression, import substitution generated a cost-push effect of high wages on inflation. During 1975-90, growing government spending, large wage increases, and inefficient production created chronic inflation that increased until the 1980s, and real per capita income fell by more than 20 percent. The annual rate of inflation never fell below 100 percent during this period. Starting with the Rodrigazo (the group of economic policies announced in Argentina on June 4, 1975), inflation rose sharply, reaching an average of more than 300 percent per year during 1975-91, and prices increased by a factor of 20 billion pesos. Foreign debt also reached a level that was equal to three quarters of gross national product. Record foreign debt interest payments, tax evasion, and capital flight resulted in a balance-of-payments crisis that plagued Argentina with severe stagflation for this period.

In 1991, the government attempted to control inflation by pegging the peso to the U.S. dollar. In addition, it began to privatize state-run enterprises on a broader basis and stop the run of government debt. Unfortunately, lacking a full commitment, the economy continued to crumble slowly and eventually collapsed in 2001 when the Argentine government defaulted on its debt. Its GDP declined by nearly 20 percent in four years, unemployment reached 25 percent, and the peso depreciated by 70 percent after being devalued and floated. Since then, the economy has started to recover.

Brazil. Figure 1D suggests that Brazil gained ground by catching up with the United States before the mid-1970s, but since then it has been unable to move up further. Brazil is the largest national economy in Latin America and is famous for its corruption (ranking 69th among 178 countries in 2012 in the Transparency International's Corruption Perceptions Index). Corruption alone costs Brazil an estimated $\$ 41$ billion a year.

Since the end of the Second World War, the Brazilian economy started intense import substitution, transformed from a largely agricultural to an industrial society, and grew more than 7 percent during 1951-60. Yet, without setting up the institutions for export growth, the economy ran a large current account deficit. With the industrialization process continuing over the following decade, export expansion led to double-digit growth.

After the first oil shock in the early 1970s, Brazil continued its high-growth policy by running up foreign debt because of increasing import requirements of industrialization. Another feature of the post-1973 period is the acceleration of inflation. During 1973-91, Brazil experienced high inflation; its annual rate was 30 to 40 percent in the 1970s and accelerated in the 1980s. Its government deficit (corrected for inflation) fell from an average of 13 percent of GDP in the early 1980s (peaking at 22.1 percent in 1983) to 3.3 percent in 1987. Capital continued to flow out of the country for more than a decade, during 1982-91, and was estimated at more than $\$ 10$ trillion per year for the second half of the 1980s (Edwards, 1998). Its inflation peaked as follows: 1986:02 (20 percent), 1987:06 (24 percent), 1989:01 (33 percent), and 1990:03 (59 percent). The 1986 Cruzado Plan and the 1990 Collor I Plan helped only temporarily. With the 1991 Collor II Plan still lacking success, Brazil continued to suffer crises, including those in 1999 and 2002; although, these crises were considerably less severe than the Argentine crisis in 2001-02. 


\section{Wang, Wong, Yip}

Chile. Chile's relative income did not rise but fell during 1970-2001 (see Figure 1D). From the Second World War to 1970, real GDP per capita of Chile increased at an average annual rate of 1.6 percent, and its economic performance was behind those of Latin America's large and medium-sized countries. Chile pursued an import-substitution strategy, which resulted in an acute overvaluation of its currency that intensified inflation. The government carried out several anti-inflation programs but failed, and inflation continued to be a serious problem of Chile's in the 1970s. However, since its adoption of its inflation target in 1991, the Chilean economy has stabilized.

Although most Latin American countries have practiced strong government intervention in the markets since the mid-1970s, Chile pursued free market reform. A group of Chicago economists - the so-called Chicago boys-were brought in for the formulation and implementation of Chile's reforms. The outcomes are as follows: Exports grew rapidly, per capita income took off, inflation declined to single digits, wages increased substantially, and the incidence of poverty plummeted (compare with Edwards and Edwards, 1991). Since the democratic administration of Patricio Aylwin in 1990, the economic reform has been accelerated and Chile has become one of the healthiest economies in Latin America.

Greece. As indicated in Figure 1D, Greece's relative income rose before 1970; since then it has been largely flat. After World War II and the civil war between communist and anti-communist forces in the 1940s, the Greek economy enjoyed rapid growth that was propelled in part by the Marshall Plan. During the 1960s-70s, the country went through a political transition, known as the Metapolitefsi.

Greece became a member of both NATO (1980) and the European Communities (1981). This facilitated foreign investments in industrial enterprises and heavy infrastructure. The rapid expansion of the service sector (mainly due to tourism) further contributed to the fastgrowing performance of the economy. In the first decade of this century, the service sector made up 85 percent of the national economic output. In addition, the country adopted the euro in 2001 and successfully hosted the 2004 Summer Olympic Games in Athens. However, by the end of 2009, Greece suffered greatly from the financial crisis that began in the United States and that has been central to the related European sovereign debt crisis recently.

Philippines. The Philippines was one of the wealthiest countries of the region in the post-war period. However, as shown in Figure 1D, its relative income has been flat over the entire sample period since then. Since the Marcos administration in the 1960s, the Philippines was overtaken by other Asian economies. The People Power Revolution of 1986 resulted in Marcos's exile to Hawaii, and Corazón Aquino became the president. However, during her administration, the economy suffered from national debt, government corruption, coup attempts, and natural disasters. When Fidel V. Ramos replaced Aquino in 1992 and liberalized the economy, there was a short recovery, which was interrupted by the 1997 Asian financial crisis.

Similar to its neighbors in the region, the Philippines suffered a fall in both the stock market and its currency value during the Asian financial crisis. Fortunately, the government was fiscally conservative because of the supervision of the IMF, and the economy has recovered since the millennium. During Gloria Macapagal-Arroyo's 9-year administration beginning in 
2001, the economy experienced GDP growth from 4 percent in 2002 to 7 percent in 2007 with the completion of infrastructure projects, such as the Manila Light Rail Transit System Line 2 in 2004, and it managed to avoid the Great Recession caused by the financial crisis of 2007-08.

\subsection{Summary and Comparison}

By reviewing the previous country-specific details, one can see that the 10 fast-growing countries have all adopted an open policy with an export-led development strategy. For instance, the 1967-71 Five-Year Economic Development Plan of South Korea focused on shifting from primary exports to manufacturing sectors. In 1974, Chiang Ching-kuo implemented the Ten Major Construction Projects that helped Taiwan transform into a growing, export-led economy. These countries have set up the environment to promote FDI. Their governments have undertaken serious reforms, particularly in both labor and financial markets. Most of them have also implemented various effective industry polices suitable to their competitive edges. Examples include the pro-market reform of China since the 1992 Southern Tour announcement by Deng Xiao-ping. In particular, the Chinese government has instituted a number of ownership, trade, and hukou (household registration) reforms and established economic and technological development zones to attract FDI. In the 1980s, Singapore set as high priority the high-tech industries (such as electronics, chemicals, and biotechnology) and pursued a high-wage policy during 1979-84 to shift production away from labor-intensive to both capital-intensive and high-tech activities.

In contrast, those African economies mired in the poverty trap have adopted import substitution policies that attracted foreign investment through protected markets. Many have financed public investment in heavy industry, which allocated lots of resources to only a thin market. To private industries, strong protectionism has stimulated domestic investment but retarded productivity and competitiveness. There has been a lack of both export diversification and production sophistication. Moreover, corruption has been severe while government allocation has been perceived as inefficient. As a result, these economies remain primarily agricultural societies. For instance, agriculture dominates the production activity of Comoros, focusing on only three main cash crops: ylang-ylang (for perfume), vanilla, and coconut. Over the past 40 years, cocoa output has grown to dominate Côte d'Ivoire's economy and world production. And GDP of both Kenya and Uganda have relied heavily on coffee production.

While the Latin American countries were at much better stages of development even relative to most of the fast-growing ones, they also have employed an import substitution strategy based on protectionism and government-heavy industrialization as in the trapped African economies. Since the oil crises in 1973 and 1979, they have all accumulated external debt at an unsustainable pace. Undisciplined fiscal expansion together with loose monetary policy have led to various high-inflation episodes, causing instability and uncertainty. Corruption and inefficient government allocation have caused resource waste. For instance, after the Great Depression, Argentina pursued a strategy of import substitution to achieve industrialization, but it eventually led to the nightmare of cost-push inflation. Similarly, the import substitution industrialization of Brazil also resulted in a substantial increase in imports and, 


\section{Table 4}

\section{Summary of Development Drivers from Country Studies}

\begin{tabular}{ll} 
Development-enhancing factors & Development-retarding factors \\
\hline (1) Export-led open policy & (1) Unnecessary protectionism \\
(2) FDI incentives & (2) Government misallocation \\
(3) Business infrastructure & (3) Corruption \\
(4) High-tech promotion & (4) Financial instability \\
(5) Pro-market labor institutions & \\
(6) Pro-market financial institutions & \\
SOURCE: Penn World Table 8.1.
\end{tabular}

hence, a large foreign debt, so the country's balance-of-payments problems increased dramatically. The remaining two development laggards, Greece and the Philippines, have experienced paths similar to the three Latin American countries, except that they have had more moderate inflation.

We summarize our findings in Table 4. On the one hand, we identify that export-led open policy, FDI incentives, solid infrastructure for business, and promotion of high-tech industries, together with other pro-market reforms in labor and financial markets, have helped fast-growing countries outgrow the United States. On the other hand, we see that unnecessary protectionism, government misallocation, corruption, and financial instability have caused the trapped and the lag-behind countries to be unable to develop along a sustainable growth path. These institutional factors can be barriers to capital markets, trade, and industrialization, which prevent the development laggards from catching up with the Joneses.

\section{CONCLUSION}

In this article, we established quantitatively that while relative TFP is a key factor for fast-growing countries to rise and for trapped economies to fall in the development process, more-severe institutional barriers are important drivers in the laggards falling behind and the poor continuing to be mired in the development trap. We also illustrated that institutional barriers have played the most important role, accounting for more than half the economic growth in fast-growing and trapped economies and for more than 100 percent of the economic growth in the lag-behind countries. We further identified that unnecessary protectionism, government misallocation, corruption, and financial instability have caused this second set of countries to either fall into the poverty trap or lag behind without a sustainable growth engine. Thus, the establishment of correct institutions and individual incentives for better access to capital markets, international trade, and industrialization can be viewed as crucial for a country to advance with sustained economic growth. 


\section{APPENDIX}

In this appendix, we provide detailed documentation for data and institutional background used herein.

\section{Data}

Our data are based on the PWT for the period 1960-2011. Real income measures are output-based real GDP $\left(\operatorname{rgdp}^{\circ}\right)$, using prices for final goods, exports, and imports in millions of 2005 U.S. dollars that are constant across countries and over time. The capital stocks are measured in the PWT by rk ${ }^{\mathrm{NA}}$, at constant national prices in millions of 2005 U.S. dollars based on investment and prices of structures and equipment. All relative income and relative factor endowment measures are relative to the comparable incomes and endowment measures in the United States.

\section{Documentation for Country-Specific Institutional Background}

General institutional background for each of the 20 countries is based on the references listed below. In cases where our citations are more substantive, we also include the references in the main text.

- Hong Kong: Morawetz (1981); Wan (2004)

- Singapore: Lim and Lloyd (1986); Otani and Sassanpour (1988)

- South Korea: Kim (1997); Wan (2004)

- Taiwan: Kuo (1983); Li (1988); Wan (2004); Lee and Wang (2011)

- Malaysia: Malaysia Directory, (2008); Malaysia Yearbook, (2015)

- Thailand: Xu and Yu (2001)

- China: Naughton (2007)

- India: Sinha (2004); Rodrik and Subramanian (2005)

- Botswana: The World Bank Profile \#34145 (2004); Sachs and Warner (1997)

- Mauritius: Svirydzenka and Petri (2014)

- Comoros: The World Factbook (2012)

- Côte d'Ivoire: Easterly (2001)

- Ghana: Lall (1990); Prescott (1998)

- Kenya: The World Factbook (2012); The World Bank (2012)

- Uganda: Byrnes (1992)

- Argentina: Rogers and Wang (1993); Donghi (2011)

- Brazil: Rogers and Wang (1993); Edwards (1998); Ferraz and Finan (2008)

- Chile: Edwards and Edwards (1991)

- Greece: Allison and Nicholaidis (1997)

- Philippines: Canlas, Khan, and Zhuang (2011); Hutchcroft (1999) 


\section{Wang, Wong, Yip}

\section{REFERENCES}

Acemoglu, D. Introduction to Modern Economic Growth. Princeton University Press, 2009.

Aghion, P.; Howitt, P. and Mayer-Foulkes, D. "The Effect of Financial Development on Convergence: Theory and Evidence." Quarterly Journal of Economics, 2005, 120, pp. 173-222.

Allison, G. T. and Nicholaidis, K. The Greek Paradox: Promise Vs. Performance. Cambridge, MA: MIT Press, 1997.

Basu, S. and Weil, D. "Appropriate Technology and Growth." Quarterly Journal of Economics, 1998, 113, pp. 1025-1054; https://doi.org/10.1162/003355398555829.

Buera, F. J. and Shin, Y. "Financial Frictions and the Persistence of History: A Quantitative Exploration." Journal of Political Economy, 2013, 121, pp. 221-272; https://doi.org/10.1086/670271.

Byrnes, R. M. Uganda: A Country Study. Washington, D.C.: Federal Research Division and Thomas Leiper Kane Collection, Library of Congress, 1992.

Canlas, D. B.; Khan, M. E. and Zhuang, J. Diagnosing the Philippine Economy: Toward Inclusive Growth. Anthem Press, 2011.

Donghi, T. H. Argentina-Economy. December 14, 2011; http://www.webcitation.org/63w7tsNNw.

Easterly, W. The Elusive Quest for Growth. Cambridge, MA: MIT Press, 2001.

Edwards, S. "Capital Flows, Real Exchange Rates, and Capital Controls: Some Latin American Experiences." NBER WP\# 6800, 1998.

Edwards, S. and Edwards, A. C. Monetarism and Liberalization: the Chilean Experiment. Chicago, IL: University of Chicago Press, 1991.

Ferraz, C. and Finan, F. "Exposing Corrupt Politicians: The Effects of Brazil's Publicly Released Audits on Electoral Outcomes." Quarterly Journal of Economics, 2008, 123, pp. 703-745; https://doi.org/10.1162/qjec.2008.123.2.703.

Hall, R. and Jones, C. "Why Do Some Countries Produce So Much More Output per Worker than Others?" Quarterly Journal of Economics, 1999, 114, pp. 83-116; https://doi.org/10.1162/003355399555954.

Hutchcroft, P. "Neither Dynamo nor Domino: Reforms and Crises in the Philippine Political Economy," in T. J. Pempel, ed., The Politics of the Asian Economic Crisis. Cornel University Press, 1999.

Kim, L. Imitation to Innovation: The Dynamics of Korea's Technological Learning. Harvard Business School Press, 1997.

Kuo, S. W.-Y. The Taiwan Economy in Transition. Westview Press, 1983.

Lall, S. Building Industrial Competitiveness in Developing Countries. Paris OECD Development Centre, 1990.

Lee, W.-C. and Wang, P. Taiwan Economic Development: From the Past to the Future (in Chinese). Taipei, Taiwan: Wunan Publishing, 2011.

Li, K. T. The Evolution of Policy Behind Taiwan's Development Success. Yale University Press, 1988.

Lim, C. Y. and Lloyd, P. Singapore: Resources and Growth. Oxford, England: Oxford University Press, 1986.

Lucas, R. E. Jr. "Why Doesn't Capital Flow from Rich to Poor Countries?" American Economic Review, 1990, 80, pp. $92-96$.

Lucas, R. E. Jr. "Some Macroeconomics for the 21st Century." Journal of Economic Perspectives, 2000, 14, pp. 159-168; https://doi.org/10.1257/jep.14.1.159.

Malaysia Industrial and Business Directory. International Business Publications, 2008.

Malaysia Recent Economic and Political Developments Yearbook. "Strategic Information and Developments." International Business Publications, 2015.

Morawetz. Why the Emperor's New Clothes Are Not Made in Colombia: A Case Study in Latin American and East Asian Manufactured Exports. Oxford, England: Oxford University Press, 1981.

Naughton, B. The Chinese Economy: Transitions and Growth. Cambridge, MA: MIT Press, 2007. 
Otani, I. and Sassanpour, C. "Financial, Exchange Rate, and Wage Policies in Singapore, 1979-86." IMF Staff Papers, 1988, 35(3), pp. 474-95; https://doi.org/10.2307/3867183.

Prescott, E. "Needed: A Theory of Total Factor Productivity." International Economic Review, 1998, 39, pp. 525-553; https://doi.org/10.2307/2527389.

Rodrik, D. and Subramanian, A. "From Hindu Growth to Productivity Surge: The Mystery of the Indian Growth Transition." IMF Staff Papers, 2005, 52, pp. 193-228.

Rogers, J. and Wang, P. "High Inflation: Causes and Consequences." Federal Reserve Bank of Dallas Economic Review, 1993, pp. 19-33.

Sachs, J. D. and Warner, A. M. "Sources of Slow Growth in African Economies." Journal of African Economies, 1997, 6, pp. 335-76; https://doi.org/10.1093/oxfordjournals.jae.a020932.

Sinha, J. B. P. Multinationals in India: Managing the Interface of Cultures. New Delhi, India: Sage Publications, 2004.

Svirydzenka, K. and Petri, M. "Mauritius: The Drivers of Growth—Can the Past be Extended?" IMF Working Paper WP/14/134, 2014.

Wan, H. Economic Development in a Globalized Environment: East Asian Evidence. Chaps. 4, 7, 8. Kluwer Academic Publishers, 2004; https://doi.org/10.1007/978-1-4419-8941-3.

Wang, Y. and Wang, P. Barriers to Health and Poverty Trap. Unpublished manuscript. The Chinese University of Hong Kong, 2015.

Wang, P.; Wong, T. N. and Yip, C. K. Technology Assimilation and Development Accounting. Unpublished manuscript. Washington University in St. Louis, 2017.

The World Bank Profile. "Botswana-Towards Prosperity for All: A Comprehensive Development Framework Profile." \#34145, 2004.

The World Bank. "Kenya Economic Update." June 2012; http://www.worldbank.org/content/dam/Worldbank/document/Africa/Kenya/kenya-economic-update-june-2012.pdf.

The World Factbook. Central Intelligence Agency. 2012; https://theodora.com/wfbcurrent/comoros/index.html.

Xu, D. and Yu, Z. "From Crisis to Recovery: East Asia Rising Again?" World Scientific, 2001. 
